\title{
IS THERE A DIFFERENCE BETWEEN TESTOSTERONE CONTENTS IN TWO POPULATIONS OF THE BLACK EARED MOUSE, LIVING UNDER SIMILAR CONDITIONS BUT WITH DIFFERENCES IN POPULATION PATTERNS?
}

\author{
Alondra CASTRO-CAMPILLO, ${ }^{1 *}$ LILIANA LEÓN-ALTAMIRANO, ${ }^{2}$ JoAQUín \\ HERRERA-MUÑOZ ${ }^{3}$ ISAÍAS SALGADO-UGARTE, ${ }^{1,4}$ ENRIQUE MENDIETA- \\ MÁRQUEZ, ${ }^{3}$ J. L. CONTRERAS-MONTIEL, ${ }^{2}$ HÉCTOR F. SERRANO,${ }^{3}$ JOSÉ $^{2}$ \\ RAMÍREZ-PULIDO ${ }^{1}$ AND ARTURO SALAME-MÉNDEZ ${ }^{2}$ \\ ${ }^{1}$ Departamento de Biología $<$ acc@xanum.uam.mx> \\ ${ }^{2}$ Departamento de Biología de la Reproducción \\ ${ }^{3}$ Departamento de Ciencias de la Salud. División de Ciencias Biológicas y de la Salud. Universidad \\ Autónoma Metropolitana, Unidad Iztapalapa. Apdo. Postal 55-535. Av. San Rafael Atlixco \# 186. Col. \\ Vicentina. Iztapalapa, CP 09340. México, D. F., México. \\ ${ }^{4}$ Departamento de Biología. Facultad de Estudios Superiores Zaragoza, Universidad Nacional \\ Autónoma de México, Batalla 5 de mayo S/N esq. Fuerte de Loreto, Col. Ejército de Oriente, \\ Iztapalapa, 09230 México, D.F., México.
}

Castro-Campillo, A., León-Altamirano, L., Herrera-Muñoz, J., Salgado-Ugarte, I., MendietaMárquez, E., Contreras-Montiel, J. L., Serrano, H. F., Ramírez-Pulido, J. \& Salame-Méndez, A. 2012. Is there a difference between testosterone contents in two populations of the Black Eared Mouse, living under similar conditions but with differences in population patterns? Acta Zoológica Mexicana (n. s.), 28(3): 525-539.

ABSTRACT. In order to answer this question, we compare intragonadal contents of testosterone $(\mathrm{T})$ in males of two neighboring populations of Peromyscus melanotis J. A. Allen and Chapman, 1897, that differ in their population density and in its seasonal fluctuations, even though they inhabit in quite similar habitat conditions. Although an affirmative answer to this question would corroborate the idea that this androgen has a density-dependent effect, since it has been proposed that $\mathrm{T}$ increases at low densities and vice versa, our results did not confirm this thesis: T showed no differences between the two populations, since both had the same seasonal pattern for the androgen, throughout four years of study, with a maximum in the summer, as would be expected in this temperate species whose reproductive optimum occurs at that time of the year. Therefore, density differences between both populations must be rather due to subtle microhabitat differences.

Key words: Denso-dependency, testosterone, Peromyscus melanotis, testes, reproduction, rodents.

Castro-Campillo, A., León-Altamirano, L., Herrera-Muñoz, J., Salgado-Ugarte, I., Mendieta-

Márquez, E., Contreras-Montiel, J. L., Serrano, H. F., Ramírez-Pulido, J. \& Salame-Méndez,

Recibido: 18/10/2011; aceptado: 13/06/2012. 
A. 2012. ¿Existe diferencia entre el contenido de testosterona en dos poblaciones del ratón de orejas negras que viven bajo condiciones similares pero con diferencias en sus patrones poblacionales? Acta Zoológica Mexicana (n. s.), 28(3): 525-539.

RESUMEN. Para abordar esta pregunta, se compara el contenido intragonadal de testosterona (T) en machos de dos poblaciones aledañas de Peromyscus melanotis J. A. Allen y Chapman, 1897, que difieren en su densidad poblacional y en sus fluctuaciones estacionales, no obstante que habitan en condiciones de hábitat muy similares. Si bien una respuesta afirmativa a la pregunta confirmaría que este andrógeno influye sobre la densidad poblacional, ya que se ha propuesto que aumenta cuando la densidad disminuye y viceversa, nuestros resultados no apoyan esta tesis: la T no mostró diferencias entre las dos poblaciones, pues ambas tuvieron el mismo patrón de contenido estacional del andrógeno con un máximo en el verano, a lo largo de cuatro años; tal como se esperaría en una especie de zonas templadas cuyo óptimo reproductivo ocurre en esa época del año. En consecuencia, las diferencias de densidad entre las poblaciones estudiadas deben estar más bien relacionadas con sutiles diferencias de microhábitat.

Palabras clave: Denso-dependencia, testosterona, Peromyscus melanotis, testículos, reproducción, roedores.

\section{INTRODUCTION}

During our studies of two populations of the Black Eared Mouse, Peromyscus melanotis J. A. Allen \& Chapman, 1897, in the Parques Nacionales "Cumbres del Ajusco" (PNAC) and "Desierto de los Leones" (PNDL), we found that the males showed a peak in their production of testosterone (T), and other sexual steroid hormones, during the summer (Salame et al. 2004, 2005), when we have noticed that the photoperiod becomes larger, temperatures are warmer and the most abundant rains occur, triggering the greening, flowering, and fructification of plants in both sites. However, against to what was expected, population densities and their fluctuations turned out to be different between the sites (Castro-Campillo et al. 2008): i. e., while P. melanotis was less abundant in the PNDL and its population peaks collapsed during winter ( $v$. $g r$., the species might not be captured at all), it turned out to be the dominant and always present, resident micro-mammal in the PNCA ( $v$. gr., it showed population peaks during the winter and especially in the summer).

Such density differences puzzled us, since in a broader sense, they would be normally expected between conspecific populations inhabiting distinct vegetation types (v. gr., according to clear differences of latitude or altitude sensu Sadleir 1969, Merritt et al. 2003), or between those conspecific populations coming from the same vegetation type but with a clear discontinuity in its degree of environmental conservation ( $v$. $g r$., pristine $v s$. disturbed sites sensu Vazquez et al. 1999, García-Estrada et al. 2002, 2004, Hernandez-Betancourt et al. 2008). Opposed to that, our two locations share many habitat similarities, since both bear coniferous and coniferous-oak temperate forests, with subtle differences in the abundance composition of understory plant species; their degree of disturbance is similar, even if the causes differ in intensity; they are very close to each other $(\leq 20 \mathrm{~km})$ and, thus, their altitude intervals overlap; 
and both belong to the same climatic type (i.e., temperate sub-humid with rains in the summer, Garcia 1981).

The clear population density differences between the sites (Castro-Campillo et al. 2008) led us to ask ourselves, from a physiological point of view, if there were differences in the intra-gonadal contents of $\mathrm{T}$ between the males of these two conspecific populations, even though they live in similar environmental conditions and both of them show a reproductive optimum during the summer (Salame-Méndez et al. 2004, 2005). The answer to this question is a necessary antecedent for exploring the possible role of $\mathrm{T}$ as a regulatory factor of population density, as has been proposed by Christian (1961, 1971) and followers (Morris 1994, Spritzer et al. 2005), based on the relationship of the androgen to recrudescence of both seminal vesicles and testes; $v$. $g r$., it is assumed that high-density populations must have low $\mathrm{T}$ contents, since their sex organs appear smaller than in low-density populations, which in turn, should show high $\mathrm{T}$ contents related to bulkier sex organs. Indeed, recrudescence of both sex organs has been directly associated to T contents (Kenagy \& Trombulak 1986, Fukazawa \& Iguchi 1999, Desai \& Kondaiah 2000, Holstein et al. 2003) but there are no previous studies in which gonadal contents of $\mathrm{T}$ had been actually compared, using conspecific populations with different density patterns.

The answer to such question is analyzed here in the light to what would be expected sensu Christian (1961, 1971) and others (Morris, 1994, Spritzer et al. 2005), according to the possible relationship of $\mathrm{T}$ contents with the differences of density fluctuations in two populations of $P$. melanotis that inhabit similar ecological conditions (Castro-Campillo et al. 2008): i. e., it would be expected that the most abundant population of $P$. melanotis in the PNCA would show lower intratesticular contents of $\mathrm{T}$ than the less abundant population at PNDL. To test these patterns, we examine intragonadal $\mathrm{T}$ contents among four years, as well as among seasonal periods.

\section{MATERIALS AND METHODS}

Study Areas. The Parque Nacional Cumbres del Ajusco (PNCA) is located to the SW of the Valley of Mexico, within the Sierra del Ajusco, and it is continued with the Sierra de Chichinautzin. The climate in the PNCA (Garcia 1981) belongs to the mesic temperate subhumids with summer rains $\left(\mathrm{C}\left(\mathrm{w}_{1}\right)(\mathrm{w})\left(\mathrm{b}^{\prime}\right) \mathrm{i}^{\prime}\right)$; higher temperatures run from April to September $\left(\right.$ mean $=15 \pm 2{ }^{\circ} \mathrm{C}$ ) and lower ones run from November to February (mean $\pm \mathrm{SDM}, 11 \pm 1^{\circ} \mathrm{C}$ ); the raining season goes from May to October with a mean precipitation of $152 \pm 22 \mathrm{~mm}$, while the raining shortage is from November to April, with a mean precipitation of $16 \pm 11 \mathrm{~mm}$. The studied population was located at $19^{\circ} 13^{\prime} 49^{\prime \prime} \mathrm{N}, 99^{\circ} 15^{\prime} 19^{\prime \prime} \mathrm{W}$, between kilometers 19 and 25 of the panoramic highway to Sierra del Ajusco, and between the 2800 and $3500 \mathrm{~m}$. The vegetation corresponds to temperate forest with seasonal plants and bunchy grasses. The trees include pines (Pinus sp.) and firs (Abies religiosa), as well as pine-oak 
(Pinus - Quercus) mixed forest. The understory consists of zacatonal (bunchy, hard, tall grasses Muhlenbergia sp., Festuca sp.), as well as abundant shrubs, especially of Senecio sp. and Salix sp., together with seasonal herbal plants, including mainly Compositae, Rosaceae, and Solanaceae, among others. The ground-storey is dominated by a diversity of mosses, lichens, and fungi.

As for The Parque Nacional Desierto de los Leones (PNDL), it is located within the Sierra de las Cruces, at the E of the Valle de Mexico, being this mountain range a continuation of the Sierra del Ajusco. The weather (García 1981) is temperate subhumid but its long summer rains turn it into the most humid of the subtypes $\left(\mathrm{C}\left(\mathrm{w}_{2}\right)\left(\mathrm{w}^{\prime}\right)\left(\mathrm{b}^{\prime}\right) \mathrm{ig}\right)$; the higher temperatures are recorded from April to July (12.6 \pm $6{ }^{\circ} \mathrm{C}$ ) and the lower temperatures from December to February (mean $=8.1 \pm 2{ }^{\circ} \mathrm{C}$ ). The rainy season runs from May to August $(235 \pm 30 \mathrm{~mm})$ and the dry season is from December to February $(12 \pm 4 \mathrm{~mm})$. The studied population was sampled at $19^{\circ} 18^{\prime}$ $17^{\prime \prime} \mathrm{N}, 99^{\circ} 19^{\prime} 14^{\prime \prime} \mathrm{W}$, from the entrance of the park, along the old highway in the Delegación Alvaro Obregón, until the kilometer 19, between 2180 and $3200 \mathrm{~m}$. The vegetation corresponds to temperate forest whose tree-storey is made up by a mixed forest of conifers (Abies - Pinus) and by mixed conifers-oak forest (Abies - Pinus - Quercus); the understory includes both shrubs, dominated by Senecio sp. and Salix sp., and herbal plants, dominated by Compositae, Rosaceae, and Solanaceae, but with no abundance of zacatonal; the ground-storey is mainly constituted by mosses and lichens, as well as fungi, together with a thick layer of fallen leaves.

Capture and preparation of mice. Monthly sampling was conducted to trap only adult males of Peromyscus melanotis (i. e., exhibiting adult pelage sensu Allen \& Chapman 1897, Hall 1981, Alvarez-Castañeda 2005, Castro-Campillo et al. 2005) in both study areas, from June 1996 to December 1999, using Sherman traps ( 8 x 9 x 23 $\mathrm{cm}$ ), baited with oat flakes, along band transects (Castro-Campillo et al. 2008). Captured specimens were taken to the laboratory and killed by cervical dislocation, the same day. We recorded the conventional body measurements of these individuals and cleaned their skeletons; some of them were also prepared as skin-skeleton, voucher specimens to be housed at the Mammal Collection of the Universidad Autónoma Metropolitana (acronym UAMI) sensu Ramírez-Pulido et al. (1989). Once it was cleaned, the skull was used to locate each specimen into an age category, according to the wear of the occlusal surface of cheek-teeth, defining three levels: young adults (III), middle aged adults (IV), and old adults (V) sensu Hoffmeister (1951).

Gonadal dissection and storing. Both testes were surgically separated from the body and their maximum length and width were recorded. The tunica albuginea was discarded from the right testis, which in turn was stored at $-70^{\circ} \mathrm{C}$ within an Eppendorf tube, containing an isotonic Ringer solution.

Quantification of testosterone. In order to determine the contents of $17 \beta-\mathrm{Hy}$ droxyandrost-4-en-3-one (testosterone, T), we used radioimmunoassay (RIA); the 
extraction processes, separation of total steroids and of $\mathrm{T}$, as well as the RIA were conducted as in Salame-Méndez et al. (2003). Briefly, the right testis was thawed out and homogenized by ultrasound to take two aliquots: one was used to determine protein contents by the method of Groves et al. (1968) and the second one to make the extraction and quantification of the androgen. First, the extraction of total steroids (ETS) in the latter aliquot was made through diethyl ether, being the efficiency of $98.6 \pm 0.6 \%$ for the procedure. The following separation of the T from the ETS was undertaken trough thin layer chromatography, using three systems of organic solvents (eleutropic phases). Once the androgen was separated, it was quantified by RIA, and this method was validated by means of a standard curve. The coefficient of variation inter-assay was $<4 \%$, correcting the result of each determination from the percentage of recuperation. The quality control of each RIA was accomplished according to international specifications of accuracy, precision, and sensitivity (Rodbard 1974, Cekan 1976).

Statistical analyses. A total of 114 male adults of Peromyscus melanotis, captured between 1996 and 1999 (Table 1), were arranged according to season and locality; the seasons of the year were considered every three months (spring = March - May, summer = June - August, autumn $=$ September - November, winter $=$ December - February). Descriptive statistics (mean; standard deviation, SD; coefficient of variation, $\mathrm{CV}$ ) of seasonal $\mathrm{T}$ contents were computed by year within each locality, by pooling all years within each locality, and by pooling data from both localities and all years in order to run further analyses (Table 1). Significant differences $(\mathrm{P}<$ 0.05 ) in the contents of intra-gonadal $\mathrm{T}$ were examined by one-way analysis of variance (ANOVA), followed by Tukey Multiple Comparisons test in three series. In one series of ANOVAs, we tested the null hypothesis of no differences of T contents within the same population by comparing the same season among the years in the same locality. In a second series of ANOVAs, we tested the null hypothesis of no inter-population seasonal differences (Fig. 1) when the same season and the same year were compared between both localities (Figs. 1a-d) and when data from the same season and locality were pooled together, independently of the year (Fig. 1e), to be compared between populations. Finally, in a third series of ANOVAs we pooled data together from both populations as follows: a) by seasons and years (Fig. 2a) in order to test the null hypothesis of no seasonal differences among years; $b$ ) by seasons independently of the year, in order to compare the overall pattern of seasonal $\mathrm{T}$ contents in both populations of P. melanotis (Fig. 2b). ANOVAs results are depicted in bar charts (Figs. 1 and 2), where the bar depicts mean intragodanal $\mathrm{T}$ contents, while the whiskers are one standard deviation of the mean. Calculations and graphics were computed with the statistical package GraphPad Prisma (ver. 5.0, Motulsky 1999). 
Castro-Campillo et al.: Does testosterone affect population density in P. melanotis?

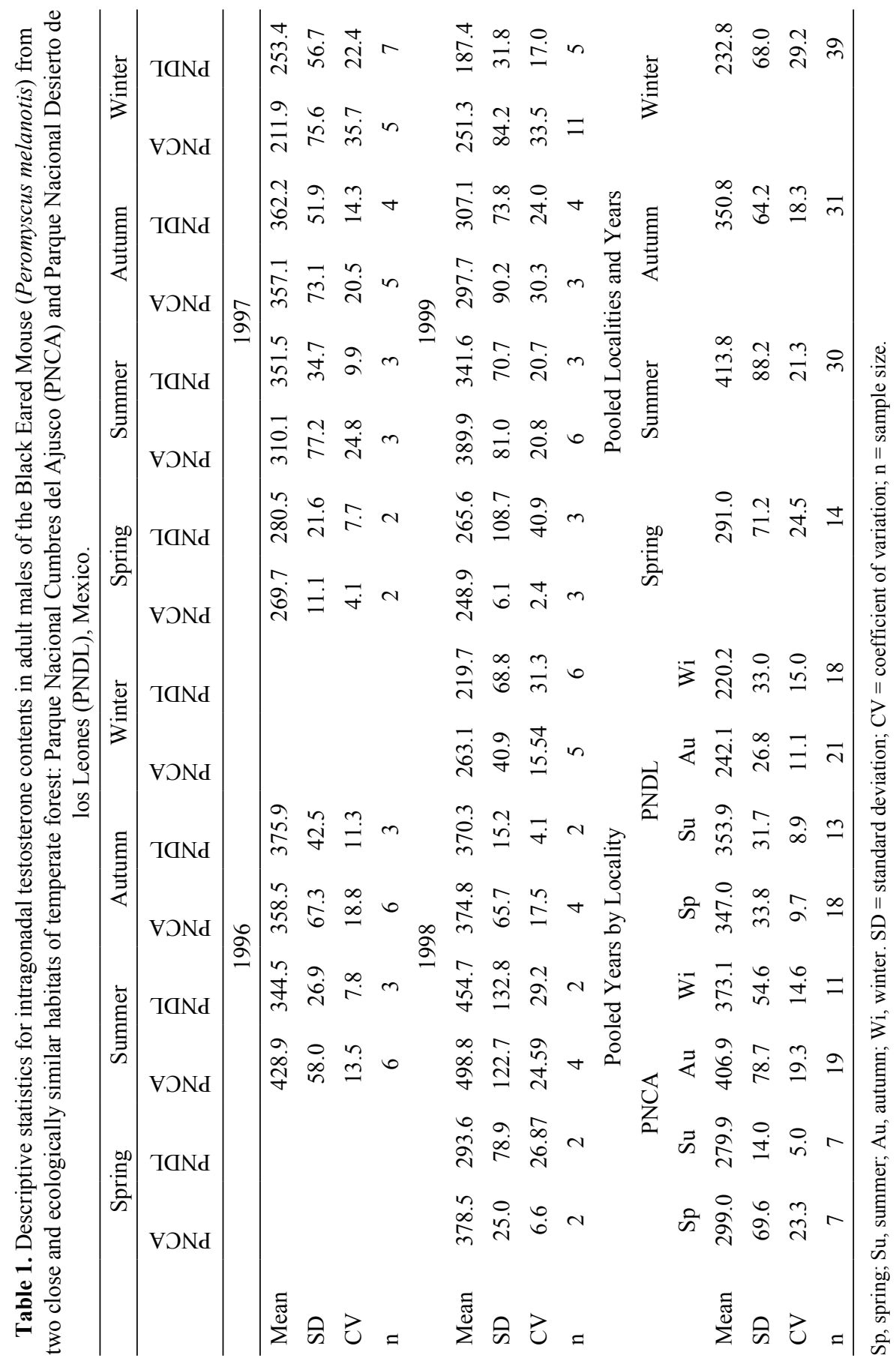


a. Spring

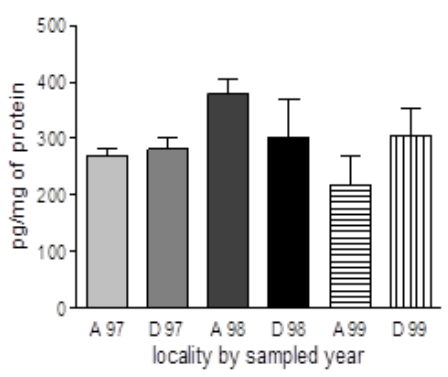

c. Autumn

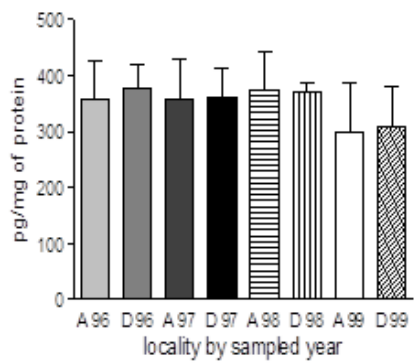

b. Summer

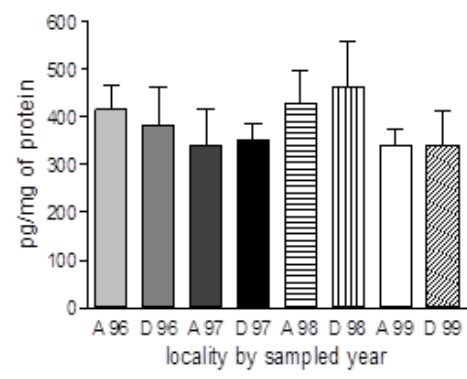

d. Winter

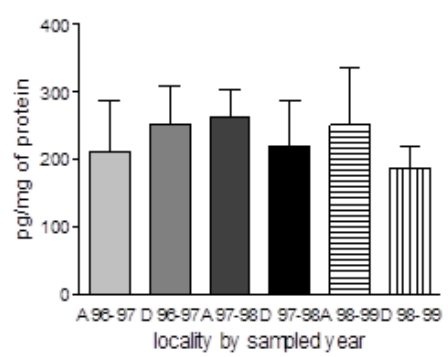

e. Pooled seasons by locality

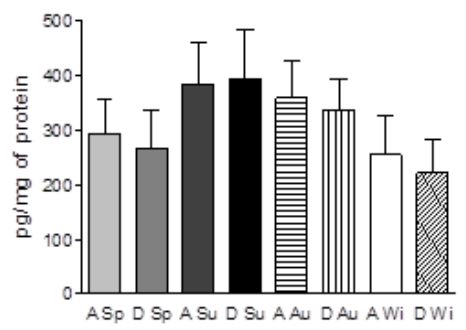

Figure 1. Comparisons of testosterone contents in the testes of adult mice Peromyscus melanotis from the Parques Nacionales "Cumbres del Ajusco" (A) and "Desierto de los Leones" (D): a.-d. Considering the seasons within the studied years 1996-1999 (96-99); e. When the seasonal data of all years were pooled together by locality. Sp, Spring; Su, Summer; Au, Autumn; Wi, Winter.

\section{RESULTS}

Table 1 shows the descriptive statistics of our data, where coefficients of variation $(\mathrm{CV})$ of intragonadal $\mathrm{T}$ contents averaged a moderate general variation (i. e., mean $\mathrm{CV} \pm \mathrm{SD}, 18.41 \pm 9.46$, minimum $=2$; maximum $=41$ ), independently of sample size 
a.

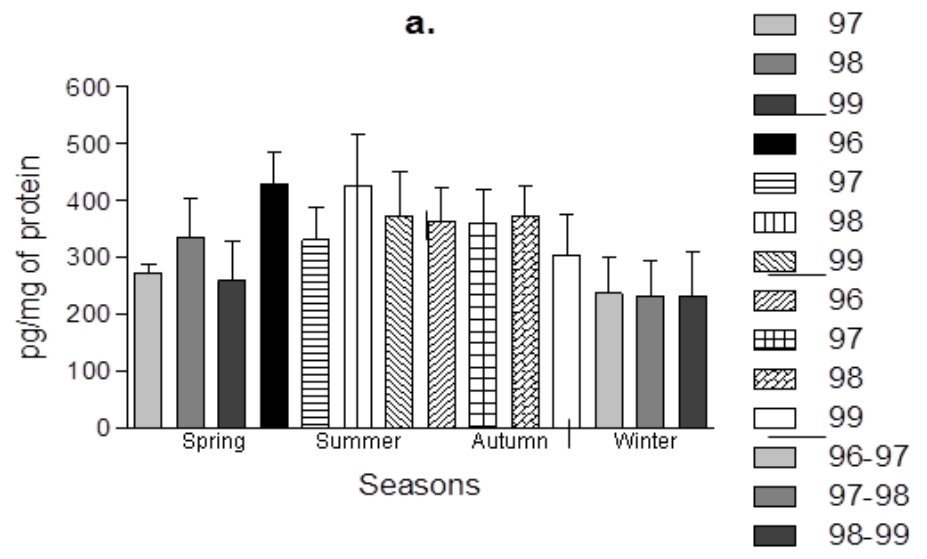

b.

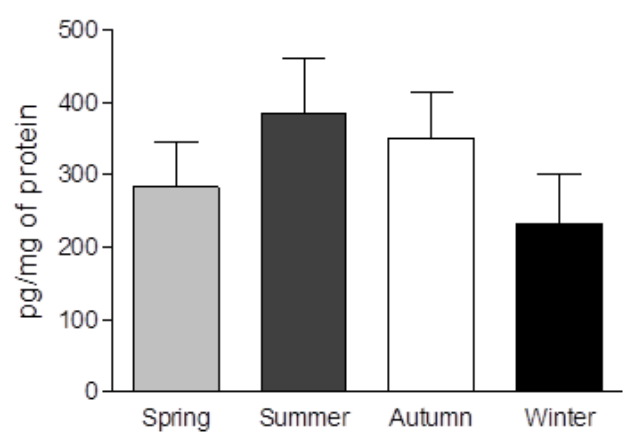

Figure 2. Comparisons of the contents of testosterone in the testes of adult mice of Peromyscus melanotis from two pooled localities, according to: a. Studied years 1996-1999 (96-99); b. Overall population seasonality of testosterone contents in both localities.

$(2>n>39)$. ANOVA outcomes for these data proved no patterns of overall variation by showing no consistent differences in $\mathrm{T}$ contents within the same population or between populations, according to the year or the season. Indeed, the first series of single ANOVA revealed no consistent differences in the intragonadal contents of $\mathrm{T}$, when the same season was compared within the same locality, with only two exceptions among the males from PNCA, including the significantly higher levels of the androgen in spring-1998, as compared to those in 1997 and $1999(\mathrm{~F}=52.3, \mathrm{df}=6, \mathrm{P}=$ $0.0014)$, respectively, as well as in the summer of the same year, against that of 1997 $(\mathrm{F}=3.09, \mathrm{df}=18, \mathrm{P}=0.0591)$, although there were no differences between summer1998 and those of 1996. When the androgen was compared between localities (Fig. 
1), its contents showed no significant differences among the same seasons along the studied years (i. e., springs, 1997-99, Fig. 1a; summers and autumns 1996-99, Figs. $1 \mathrm{~b}$ and 1c, respectively; winters, 1996-97, 1997-98 y 1998-99, Fig. 1 d). There was a certain tendency to differentiate in the spring of PNCA and in the summer of PNDL of 1998, since contents of T were higher; however, the pattern was still no consistent among years, seasons nor localities. Absence of significant differences was reiterated when data from different years were pooled in seasonal comparisons between localities (Fig. 1e); indeed, the analyses showed that the increasing-decreasing intra-population profile of seasonal $\mathrm{T}$ contents was shared by both localities. When data from both localities were pooled together by season, to compare values among years, no significant differences were either found among the same seasons (Fig. 2a). If pooled data from both localities and years were examined by season, $T$ contents was significantly higher in the summer, compared to all the other seasons $(\mathrm{P}<0.0001$, Fig. $2 \mathrm{~b})$; similarly, the androgen contents was significantly higher $(\mathrm{P}<0.001)$ when autumn was compared to winter, although it was similar between the latter and the spring.

\section{DISCUSSION}

Besides to the release of sexual behavior (i. e., quest of mates, courtship displays, physiological processes) and mating (Clemens \& Pomenrantz 1982, vom Saal 1983, Ligon et al. 1990, Gouchie \& Kimura 1991, Zielinski \& Vandenbergh 1993, Ferkin et al. 1994, Rhen \& Crews 2002, Hirschenhauser \& Oliveira 2006, Spritzer et al. 2005, Waterman 2007), elevation of T contents also induces recrudescence of seminal vesicles and testes, as well as spermatogenesis in males (Kenagy \& Trombulak 1986, Zirkin 1998, Fukazawa \& Iguchi 1999, Desai \& Kondaiah 2000, Holstein et al. 2003, Nelson 2005). In fact, T has also been related to capabilities that might involve better probabilities for males to survive, enhance their self-defense and gathering of territory and mates, as well as their reproductive success, such as vagility, spatial ability, dominance rank, and aggressiveness (Christian 1971, vom Saal 1987, Gipps 1982, Perrot-Sinal et al. 1998, Spritzer et al. 2005). Based only on the size of some reproductive organs and accessory glands, Christian $(1961,1971)$ proposed that $T$ could have different density-dependent effects. This author proposed that "a series of feed-back mechanisms, particularly involving the pituitary-adrenocortical and pituitary-gonadal systems, which in turn can be activated by socio-psychological factors (intraspecific competition) within the population, could be responsible for changes in population size". He continues on stating that "interacting behavioral and endocrine mechanisms comprise at least an important part of a system responding to changes in the number of animals in such a way that population growth is self-limiting and self-regulating".

However, before our study, the contents of the androgen had not been actually measured for that purpose in wild populations; $v . g r$., in two populations of the same 
species with different patterns of density fluctuations (Castro-Campillo et al. 2008). The more proximate studies have been the measurement of $\mathrm{T}$ levels with respect to depletion of immune response, which in turn derives in a higher susceptibility to parasites; in fact, results of this research line have proved increasing of morbility as a density-dependent event, which in turn has been associated to reduction of population size in disturbed environments (Cook \& Beer 1955, Alexander \& Stimson 1988, O1sen \& Kovacs 1996, Barnard et al. 1998, 2002, 2003, Burthe et al. 2006, Ostfeld et al. 2006, Radwan et al. 2009, Luis et al. 2010). Nevertheless, we found no differences in the intragonadal contents of $\mathrm{T}$, between the males of the two populations studied: independently of how many more males can be found in PNCA all year round, as compared to those from PNDL (Castro-Campillo et al. 2008), their gonads produce as many as much $\mathrm{T}$ as the latter (Figs. 1-2). In addition, when we reviewed data of intragonadal $\mathrm{T}$ contents, against population density fluctuations in each locality (see Fig. 1 and Appendix in Castro-Campillo et al. 2008), we neither found a consistent foundation for the idea that a decreasing of population density, triggers an increasing of $\mathrm{T}$, or vice versa.

Therefore, independently of population size and its fluctuations (Castro-Campillo et al. 2008), the endocrine function in adult males of $P$. melanotis is seasonally related in both localities: it is more active from spring to summer, and less active from autumn to winter (see Salame-Méndez et al. 2004 and Fig. 2b here). Moreover, in spite of the relative harshness of environmental conditions during winter, it is also true that neither spermatogenesis nor $\mathrm{T}$ contents are ceased, a fact that supports reproduction of $P$. melanotis in both localities all year round (Salame-Méndez et al. 2004, 2005). Since abundance differences between both populations did not show a connection with an endocrine variation of intragonadal contents of $\mathrm{T}$, it might be that differences in fluctuations between the two localities are rather a by-product of subtle changes in the abiotic and biotic factors of their respective habitats, in spite of its geographic nearness and its first-glance environmental similitude. In fact, the seasonal behavior of intragonadal $\mathrm{T}$ contents in $P$. melanotis shows an ecophysiological pattern of summer optima in these two populations, living in temperate forests at the studied latitude, between $2100-3500 \mathrm{~m}$. Such pattern, as we have observed, is clearly more related to seasonality of rainfalls and to the subtle changes in temperature $\left(\mathrm{T}^{\circ}\right)$, during the summer, which in both localities provide the foundations for the greening, flowering, and fruiting of plants. The consequent availability and diversification of food resources, generates a peak for intragonadal $\mathrm{T}$ contents, which in turns triggers the reproductive activities of the Black Eared mouse in both localities. Then, as the rains decline, from summer to autumn, and the $\mathrm{T}^{\circ}$ drops (García 1981), vegetation also dries out during the winter and levels of $\mathrm{T}$ become lowest. Therefore, the ecophysiological pattern of intragonadal $\mathrm{T}$ contents in $P$. melanotis concurs with the idea that environmental factors are determinant to the dynamics of the reproductive 
biology of mice (Sadleir 1969, Merrit et al. 2003, Galindo-Leal \& Krebs 1998; Hernandez-Betancourt et al. 2008), rather to the idea that $\mathrm{T}$ could be acting as a regulator of population density.

Indeed, the effect of annual changes in environmental conditions of habitat over wild mice populations, has been well documented in terms of density fluctuations, as well as through the onset and seasonality of its reproductive activity; moreover it is accepted that characteristics and variation of environmental conditions regulate both aspects in their life histories (Lackey 1978, Millar 1984, Knapp 1989, Millar et al. 1990, Heideman \& Bronson 1992, 1993, Galindo-Leal \& Krebs 1997, 1998, Lima et al. 2001, 2002, Merritt et al. 2003, Luis et al. 2010). Accordingly, a general pattern for species inhabiting temperate regions, such as P. melanotis, is that the optimal season for reproduction is fixed during the spring or the summer with respect to the annual cycle, especially as a function of variations in the light period, temperature, precipitation, and access to food resources that can imply either an insurance or a risk for the reproductive investment (Sadleir 1969, Merritt et al. 2003). In addition, the onset of reproductive activity is linked to the rising of steroid sexual hormones (SSH) - particularly of testosterone (T) in adult males, which are therefore the ones in charge of reproducing the population (Anderson 1989, Kunz et al. 1996). Rising of SSH in P. melanotis seems to be also synchronized to the changes in the environment (Salame-Méndez et al. 2004, 2005), in order to secure optimal conditions for its reproduction (Bronson \& Heideman 1994; Bartness \& Albers 2000).

\section{DEDICATION}

We honor the memory of our dear friend, Juan Patiño-Rodríguez (1953-2011). Johnny, as we friendly called him, was the collecting and taxidermist technician of the Mammal Collection of the Autonomous Metropolitan University, at Iztapalapa (UAMI) since 1978. His loyal support in both the field and laboratory work was always committed, responsible and professional, becoming a crucial part of our studies. More importantly, his deep taste for life and his joyful spirit always facilitated our work in difficult as well as in every-day moments.

ACKnowledgements. We thank Rosa M. Gómez-Ugalde as well as many of our undergraduate and graduate students, now our colleagues, for their collaboration in field work. Jorge Cumate guided us in the recognition of vegetation strata and its dominant taxa. Olga Moreno-Ramos, Daniel Díaz-Porras and Heriberto Ramírez-Ruiz participated in data organization and data capturing. This study was partially funded by the Division of Biological and Health Sciences at UAMI, through research projects (ASM, ACC), CONACyT (JRP), and PROMEP, SEP (CA-27 CABMS, ASAM, ACC, and JRP).

\section{LITERATURE CITED}

Alexander, J. \& Stimson, W. H. 1988. Sex hormones and the course of parasitic infection. Parasitology Today, 4: 89-193. 
Allen, J. A. \& Chapman, F. M. 1897. On a collection of mammals from Jalapa and Las Vigas, State of Vera Cruz, Mexico. American Museum of Natural History, 9: 197-268.

Alvarez-Castañeda, S. T. 2005. Peromyscus melanotis. Mammalian Species, No. 764: 1-4.

Anderson, P. K. 1989. Dispersal in rodents: A resident fitness hypothesis. Special publications No. 9. American Society of Mammalogists, Provo, UT, $141 \mathrm{pp.}$

Barnard, C. J., Behnke, J. M., Bajer, A., Bray, D., Race, T., Frake, K., Osmond, J., Dinmore, J. \& Sinski, E. 2002. Local variation in endoparasite intensities of bank voles (Clethrionomys glareolus) from ecologically similar sites: morphometric and endocrine correlates. Journal of Helminthology, 76: 103-112.

Barnard, C. J., Behnke, J. M., Gage, A. R., Brown, H. \& Smithurst, P. R. 1998. The role of parasite-induced immunodepression, rank and social environment in the modulation of behaviour and hormone concentration in male laboratory mice (Mus musculus). Proceedings of the Royal Society of London B, 265: 693-701.

Barnard, C. J., Kulis, K., Behnke, J. M., Bajer, A., Gromadzka-Ostrowska, J., Stachon, M. \& Sinski, E. 2003. Local variation in helminth burdens of bank voles (Clethrionomys glareolus) from ecologically similar sites: temporal stability and relationships with hormone concentrations and social behaviour. Journal of Helminthology, 77: 185-195.

Bartness, T. J. \& Albers, H. E. 2000. Activity patterns and biological clock in mammals, pp. 23-47. In: S. Halle \& N. C. Stenseth (Eds.). Activity patterns in small mammals: an ecological approach. Ecological Studies 141, Springer-Verlag, Berlin Heidelberg, 320 pp.

Bronson, F. H. \& Heideman, P. D. 1994. Seasonal regulation of reproduction in mammals, pp. 541584. In: E. Knobil \& J. D. Neill (Eds.). The physiology of reproduction. $2^{\text {nd }}$ ed., Raven Press, Ltd., N. Y., Vol. 2, 1372 pp.

Burthe, S., Telfer, S., Lambin, X., Bennett, M., Carslake, D., Smith, A. \& Begon, M. 2006. Cowpox virus infection in natural field vole Microtus agrestis populations: delayed density dependence and individual risk. Journal of Animal Ecology, 75: 1416-1425.

Castro-Campillo, A., Martínez-Coronel, M., Aguilera, U. \& Ramírez-Pulido, J. 2005. Peromyscus melanotis (J. A. Allen \& Chapman, 1897), pp. 754-755. In: G. Ceballos \& G. Oliva (Coords.). Los mamíferos de México. Fondo de Cultura Económica, Comisión para el Conocimiento y Uso de la Biodiversidad, México, 986 pp.

Castro-Campillo, A., Salame-Méndez, A., Vergara-Huerta, J., Castillo, A. \& Ramírez-Pulido, J. 2008. Fluctuaciones de micromamíferos terrestres en bosques templados aledaños a la ciudad de México, Distrito Federal, pp. 391-410. In: C. Lorenzo, E. Espinosa \& J. Ortega (Eds.). Avances en el estudio de los mamíferos de México. Publicaciones especiales, Vol. II, Asociación Mexicana de Mastozoología, A. C., México, D. F., 691 pp.

Cekan, S. Z. 1976. Reliability of steroid radioinmunoassays. Acta Universitas Upsaliensis. (Swedish Medical Council of Reproductive Endocrinology. Research Unit. Stockholm, Uppsala, Sweden), No. 14: 1-48.

Christian, J. J. 1961. Phenomena associated with population density. Anthropology, 47: 428-449.

Christian, J. J. 1971. Fighting, maturity, and population density in Microtus pennsylvanicus. Journal of Mammalogy, 52: 556-567.

Clemens, L. \& Pomerantz, S. 1982. Testosterone acts as a prohormone to stimulate male copulatory behavior in male Deer Mice (Peromyscus maniculatus bairdii). Journal of Comparative Physiology and Psychology, B4a, 96: 114-112.

Cook, E. F. \& Beer, J. R. 1955. The louse populations of some cricetid rodents. Parasitology, 45: 409-420. 
Desai, K. V. \& Kondaiah, P. 2000. Androgen ablation results in differential regulation of transforming growth factor beta isoforms in rat male accessory sex organs and epididymis. Journal of Molecular Endocrinology, 24: 253-260.

Ferkin, M. H., Sorokin, E. S., Renfroe, M. W. \& Johnston, R. E. 1994. Attractiveness of male odors to females varies directly with plasma testosterone concentration in meadow voles. Physiology \& Behavior, 55: 347-353.

Fukazawa, Y. \& Iguchi, T. 1999. Effects of hormones and growth factors on the development of the male mouse reproductive tract in vitro. Zoological Science, 16: 153-160.

Galindo-Leal, C. \& Krebs, C. J. 1997. Habitat structure and demographic variability of habitat specialist: the Rock Mouse (Peromyscus difficilis). Revista Mexicana de Mastozoología, 2: 72-89.

Galindo-Leal, C. \& Krebs, C. J. 1998. Effects of food abundance on individuals and populations of the Rock Mouse (Peromyscus difficilis). Journal of Mammalogy, 79: 1131-1142.

García, E. 1981. Modificaciones al Sistema de Clasificación Climática de Köppen (para adaptarlo a las condiciones de la República Mexicana). Instituto de Geografía, Universidad Nacional Autónoma de México, $3^{\mathrm{a}}$ ed., México, D. F., 252 pp.

García-Estrada, C., Romero-Almaraz, M. L. \& Sánchez-Hernández, C. 2002. Comparison of rodent communities in sites with different degrees of disturbance in deciduous forest of southeastern Morelos, Mexico. Acta Zoológica Mexicana (n. s.), 85: 153-168.

García-Estrada C., Romero-Almaraz, M. L. \& Sánchez-Hernández, C. 2004. Diferencias en la actividad reproductiva de dos comunidades de roedores en el sureste del estado de Morelos, México, pp. 161-170. In: A. Castro-Campillo \& J. Ortega. (Eds.). Homenaje a la trayectoria mastozoológica de José Ramírez Pulido. Universidad Autónoma Metropolitana, Unidad Iztapalapa, México, 234 pp.

Gipps, J. H. W. 1982. The effects of testosterone and scopolamine $\mathrm{HBr}$ on aggressive behaviour of male voles, Microtus townsendii. Canadian Journal of Zoology, 60: 946-950.

Gouchie, C. \& Kimura, D. 1991. The relationship between testosterone levels and cognitive ability patterns. Psychoneuroendocrinology, 16: 323-334.

Groves, W. E., Davis, Jr., F. C. \& Sells, B. H. 1968. Spectropothometric determination of microgram quantities of protein without nucleic acid interference. Analytical Biochemistry, 22: 195-210.

Hall, E. R. 1981. The Mammals of North America. John Wiley \& Sons, Vol. 2, N. Y., vi+ 601+ 1181+ $190 \mathrm{pp}$.

Heideman, P. D. \& Bronson, F. H. 1992. A pseudoseasonal reproductive strategy in a tropical rodent, Peromyscus nudipes. Journal of Reproduction and Fertility, 95: 57-67.

Heideman, P. D. \& Bronson, F. H. 1993. Potential and realized reproduction in a tropical population of Peromyscus. (Rodentia). Journal of Mammalogy, 74: 261-269.

Hernández-Betancourt, S. F., Cimé-Pool, J. A. \& Medina-Peralta, S. 2008. Ecología poblacional de Heteromys gaumeri en la selva del sur de Yucatán, México, pp. 427-448. In: C. Lorenzo, E. Espinosa \& J. Ortega (Eds.). Avances en el estudio de los mamíferos de México. Publicaciones especiales, Vol. II, Asociación Mexicana de Mastozoología, A. C., México, D. F., 691 pp.

Hirschenhauser, K. \& Oliveira, R. F. 2006. Social modulation of androgens in male vertebrates: metaanalyses of the challenge hypothesis. Animal Behaviour, 71: 265-277.

Hoffmeister, D. F. 1951. A taxonomic and evolutionary study of the Pinon Mouse, Peromyscus truei. Illinois Biology Monographs, 21: IX+1-104.

Holstein, A. F., Schulze, W. \& Davidoff, M. 2003. Understanding spermatogenesis is a prerequisite for treatment. Reproduction Biology and Endocrinology, 1: 107-123.

Kenagy, G. J. \& Trombulak, S. C. 1986. Size and function of mammalian testes in relation to body size. Journal of Mammalogy, 67: 1-22. 
Knapp, R. 1989. The effect of red light on reproduction in Peromyscus maniculatus. Journal of Mammalogy, 70: 341-346.

Kunz, T. H., Wemmer, C. \& Hayssen, V. 1996. Sex, age, and reproduction, pp. 279-290. In: D. E. Wilson, F. R. Cole, J. D. Nichols, R. Pudran \& M. S. Foster (Eds.). Measuring and monitoring biological diversity: standard methods for mammals. Smithsonian Institution Press, Washington, D. C., $440 \mathrm{pp}$.

Lackey, J. A. 1978. Reproduction, growth and development in high-latitude and low-latitude populations of Peromyscus leucopus (Rodentia). Journal of Mammalogy, 59: 69-83.

Ligon, J. D., Thornhill, R., Zuk, M. \& Johnson, K. 1990. Male-male competition, ornamentation and the role of testosterone in sexual selection in red jungle fowl. Animal Behaviour, 40: 367-373.

Lima, M., Julliard, R., Stenseth, N. C. \& Jaksic, F. M. 2001. Demographic dynamics of a Neotropical small rodent (Phyllotis darwini): feedback structure, predation and climatic factors. Ecology, 70: 761-775.

Lima, M., Stenseth, N. C. \& Jaksic, F. M. 2002. Population dynamics of a South American rodent: seasonal structure interacting with climate, density dependence and predator effects. Proceedings of the Royal Society of London, B 269: 2579-2586.

Luis, A. D., Douglass, R. J., Mills, J. N. \& Bjørnstad, O. N. 2010. The effect of seasonality, density and climate on the population dynamics of Montana deer mice, important reservoir hosts for Sin Nombre hantavirus. Journal of Animal Ecology, 79: 462-470.

Merritt, J. F., Lima, M. \& Bosinovic, F. 2003. Seasonal regulation in fluctuating small mammal populations: feedback structure and climate. Oikos, 94: 505-514.

Millar, J. S. 1984. Reproduction and survival of Peromyscus in seasonal environments. Special Publications of the Carnegie Museum of Natural History, 10: 253-266.

Millar, J. S., Xia, X. \& Norrie, M. B. 1990. Relationships among reproductive status, nutritional status, and food characteristics in a natural population of Peromyscus maniculatus. Canadian Journal of Zoology, 69: 555-559.

Morris, D. W. 1994. Habitat matching: alternatives and implications to populations and communities. Evolutionary Ecology, 8: 387-406.

Motulsky, H. J. 1999. Analizing data with GraphPad Prism. A companion to GraphPad Prism version 3. GraphPad Software Inc., San Diego, CA, 193 pp.

Nelson, R. J. 2005. An introduction to behavioral endocrinology. $3^{\text {a }}$ ed., Sinauer Associates, Sunderland, MA, $933 \mathrm{pp}$.

Olsen, N. J. \& Kovacs, W. J. 1996. Gonadal steroids and immunity. Endocrine Reviews, 17: 369-384.

Ostfeld, R. S., Canham, C. D., Oggenfuss, K., Winchcombe, R. J. \& Keesing, F. 2006. Climate, deer, rodents, and acorns as determinants of variation in Lyme-disease risk. PLoS Biol, 4: e145.

Perrot-Sinal, T. S., Innes, D., Kavaliers, M. \& Ossen, K. P. 1998. Plasma testosterone levels are related to various aspects of locomotor activity in wild-caught male Meadow Voles (Microtus pennsylvanicus). Physiology \& Behavior, 64: 31-6.

Radwan, J., Biedrzycka, A. \& Babik, W. 2009. Does reduced MHC diversity decrease viability of vertebrate populations? Biology of Conservation, 143: 537-544.

Ramírez-Pulido, J., Lira, I., Gaona, S., Müdespacher, C. \& Castro, A. 1989. Manejo y mantenimiento de colecciones mastozoológicas. Universidad Autónoma Metropolitana, Unidad Iztapalapa, México, D. F., 127 pp.

Rhen, T. \& Crews, D. 2002. Variation in reproductive behavior within a sex: neural systems and endocrine activation. Journal of Neuroendocrinology, 14: 517-531.

Rodbard, D. 1974. Statistical quality control and routine data processing for radioimmunoassay and immunoradiometric assays. Clinical Chemistry, 20: 1255-1270. 
Sadleir, R. M. F. S. 1969. The ecology of reproduction in wild and domestic mammals. Methuen and Co. Ltd., London, $321 \mathrm{pp}$.

Salame-Méndez, A., Castro-Campillo, A., Mendieta-Márquez, E., Salgado-Ugarte, I. H., HerreraMuñoz, J. \& Ramírez-Pulido, J. 2004. Evaluación estacional de la producción de esteroides sexuales en testículos del ratón de orejas oscuras (Peromyscus melanotis Allen \& Chapman, 1897) de diferentes clases de edad. Acta Zoológica Mexicana (n. s.), 20: 103-114.

Salame-Méndez, A., Vigueras-Villaseñor, R. M., Castro-Campillo, A., Herrera-Muñoz, J., Mendieta-Márquez, E. \& Ramírez-Pulido, J. 2005. Descripción del perfil ontogenético de hormonas esteroides sexuales e intermediarios en testículos del ratón de orejas negras (Peromyscus melanotis Allen y Chapman, 1897). Revista de la Sociedad Mexicana de Historia Natural, $3^{a}$ Época, volumen dedicado en Homenaje al Dr. Eucario López-Ochoterena, vol. II: 193-199.

Salame-Méndez, A., Vigueras-Villaseñor, R. M., Herrera-Muñoz, J., Mendieta-Márquez, E., Salgado-Ugarte, I. H., Castro-Campillo, A. \& Ramírez-Pulido, J. 2003. Inmunolocalización y contenido de esteroides sexuales en ovarios de hembras de Peromyscus melanotis Allen y Chapman, 1897 (Rodentia: Muridae) durante la primera mitad de la preñez. Acta Zoológica Mexicana (n. s.), 88: $43-57$.

Spritzer, M. D., Meikle, D. B. \& Solomon, N. G. 2005. Female choice based on male spatial hability and aggressiveness among meadow voles. Animal Behaviour, 69: 1121-1130.

Vázquez, L. B., Cameron, G. N. \& Medellín, R. A. 1999. Hábitos alimentarios y biología poblacional de dos especies de roedores en el Occidente de México. Revista Mexicana de Mastozoología, 4: 5-21.

vom Saal, F. S. 1983. Introduction. The interaction of circulating oestrogens and androgens in regulating mammalian sex differentiation, pp. 159-177. In: J. Balthazart, E. Pröve \& R. Gilles (Eds.). Hormones and behaviour in higher vertebrates. Springer-Verlag, Berlin, Heidelberg, 489 pp.

vom Saal, F. S. 1987. Perinatal testosterone exposure has opposite effects on adult intermale aggression and infanticide in mice, pp. 179-204. In: P. F. Brain, D. Mainardi \& S. Parmigiani (Eds.). House mouse aggression: a model for understanding the evolution of social behaviour. Ettore Majorana International Life Science Series. Hardwood Academic Publishers, N.Y., 339 pp.

Waterman, J. 2007. Male mating strategies in rodents. pp 27-41. In: J. O. Wolff \& P. W. Sherman (Eds.). Rodent societies: an ecological and evolutionary perspective. The University of Chicago Press, Chicago, IL, 610 pp.

Zielinski, W. J. \& Vandenbergh, J. G. 1993. Testosterone and competitive ability in male house mice, Mus musculus: laboratory and field studies. Animal Behaviour, 45: 873-891.

Zirkin, B. R. 1998. Spermatogenesis: its regulation by testosterone and FSH. Seminars in Cell and Developmental Biology, 9: 417-421. 